\title{
Synthesis and Characterization with Antimicrobial Activity Studies on some Transition Metal Complexes of N, O Donor Novel Schiff Base Ligand
}

\author{
M. S. Hossain, C. M. Zakaria, M. K. Zahan* \\ Department of Chemistry, University of Rajshahi, Rajshahi-6205, Bangladesh
}

Received 28 September 2016, accepted in final revised form 7 February 2017

\begin{abstract}
Metal complexes of $\mathrm{Mn}(\mathrm{II}), \mathrm{Fe}(\mathrm{II}), \mathrm{Co}(\mathrm{II})$ and $\mathrm{Cd}(\mathrm{II})$ ions with Schiff base ligand 4\{(pyridin-2-ylimino)methyl $\}$ phenol derived from condensation of 2 -amino pyridine with 4hydroxybenzaldehyde was prepared. The ligand and complexes were isolated from the reaction in the solid form and characterized by conductivity, magnetic moment, TLC, IR, UV-Visible, thermal analysis and some physical measurements. During complexation reaction with transition metal ions Schiff base act as a deprotonated tridentate ligand and IR spectra showed that $\mathrm{N}$ and $\mathrm{O}$ atoms are coordinated to the central metal atom. The observed values confirmed that the complexes have octahedral geometry. The Schiff base and its metal complexes have been found to have moderate to strong antibacterial activity.
\end{abstract}

Keywords: Schiff base; Metal complex; Spectral analysis; Antibacterial activity; TGA and DTG.

(C) 2017 JSR Publications. ISSN: 2070-0237 (Print); 2070-0245 (Online). All rights reserved. doi: http://dx.doi.org/10.3329/jsr.v9i2.29780 J. Sci. Res. 9 (2), 209-218 (2017)

\section{Introduction}

Schiff base named after Hugo Schiff (1864) are the compounds containing azomethine group $(-\mathrm{HC}=\mathrm{N}-)$ formed by the condensation reaction of any primary amine with aldehyde or ketone under specific condition [1]. Schiff bases are the nitrogen analogue of aldehyde or ketone in which the active carbonyl group $(>\mathrm{C}=\mathrm{O})$ is replaced by an imine or azomethine group. These bases can be effective chelating agents either the carbonyl compound as the amine or both contain potentially coordinating functional groups near the site of condensation. Schiff base constitutes a very important group of $\mathrm{N}, \mathrm{O}$ donor chelating ligands [2]. Schiff bases are some of most widely used organic compounds. They are used as pigments and dyes, catalysts, intermediate in organic synthesis, and as a polymer stabilizer [3]. On the other hand, Inorganic elements play crucial role in biological and biological medical processes, and it is evident that many organic compounds used in medicine do not have a purely organic mode of action, some of them are activated or bio transformed by metal ions metabolism. Many drugs possess modified

* Corresponding author: kudrat.chem@ru.ac.bd 
toxicological and pharmacological properties in the form of metal complex and probably Schiff bases are versatile $>\mathrm{C}=\mathrm{N}$ (imine) containing compounds possessing broad spectrum of biological activity and incorporation of metals in the form of complexes showed some degree of antibacterial, antifungal, antitumor, anticancer and anti-inflammatory activity [4-8]. In vivo studies have indicated that some biologically active compounds may become more carcinostatic and bacteriostatic upon chelation [9-13]. Such interaction with transition metal ions with amino acids, peptides and nucleic acids, are of immense biological importance [14-16]. Several reviews [17-20] showed that the metallo-organic chemistry of such compounds greatly influence their biological action highlighting the catalytic function metals [21-23] in many biological processes. H. Chohan et al. [24] was reported some substituted pyridine Schiff bases obtained from salicylaldehyde and showed good antibacterial activity. Recently, we have reported some Schiff base metal complexes and their biological application from our laboratory [25,26]. Keeping these facts in view the significance of metal in biology, we here in report the synthesis and characterization of a novel Schiff base ligand derived from 2-amino pyridine with 4-Hydroxy benzaldehyde and its $\mathrm{Mn}(\mathrm{II}), \mathrm{Fe}(\mathrm{II}), \mathrm{Co}(\mathrm{II})$, and $\mathrm{Cd}(\mathrm{II})$ complexes.

\section{Experimental}

\subsection{Materials and instruments}

All chemicals and solvents used were of Analar grade. All metal(II) salts were used as chloride and sulphate. The solvents such as ethanol, methanol, chloroform, diethyl ether, petroleum ether and acetonitrile were purified by distillation procedure. The melting point or the decomposition temperature of all the prepared ligand and metal complexes were observed in an electro thermal melting point apparatus model No. AZ6512. Infrared spectra were recorded on a FTIR-8400, SHIMADZU, Japan using a $\mathrm{KBr}$ disc, in Central Science Lab of Rajshahi University. The thermogravimetric analysis (TGA) was performed on Perkin Elmer Simultaneous Thermal Analyzer, STA-8000. The electronic spectrum of the complex in solution phase $\left(5 \times 10^{-4} \mathrm{M}\right)$ was recorded on a Shimadzu Double Beam spectrophotometer model UV-1200 and UV-1650PC. The SHERWOOD SCIENTIFIC Magnetic Susceptibility Balance that following the Gouy Method were used to measure the magnetic moment of the solid complexes. The electrical conductance measurements were made at room temperature in freshly prepared aqueous solution $\left(10^{-3}\right.$ M) and in DMSO using a WPACM35 conductivity meter and a dip-cell with a platinum electrode. The purity of the ligand and metal complexes were tested by Thin Layer Chromatography (TLC).

\subsection{Preparation of schiff base}

4-hydroxy Benzaldehyde (1.2 g, $10 \mathrm{mmol})$ dissolved in absolute ethanol (20 mL) was added drop wise to a constant stirring solution of 2-amino pyridine $(0.941 \mathrm{~g}, 10 \mathrm{mmol})$ in $30 \mathrm{~mL}$ ethanol with $2 \mathrm{~mL}$ of conc. $\mathrm{H}_{2} \mathrm{SO}_{4}$ and the mixture was refluxed for $4 \mathrm{~h}$. On 
cooling, a solid white product was formed which was filtered, washed with ethanol, acetone and diethyl ether and dried in vacuum over anhydrous $\mathrm{CaCl}_{2}$. The reaction was monitored by TLC using petroleum ether, ethyl acetate, toluene and methanol solvents. The product was found to be soluble in methanol, chloroform and DMSO and insoluble in ethanol, acetone, diethyl ether, petroleum ether and isopropanol. It provided $72 \%$ yield at $36^{\circ} \mathrm{C}$. The structure of Schiff base was shown in (Scheme 1).

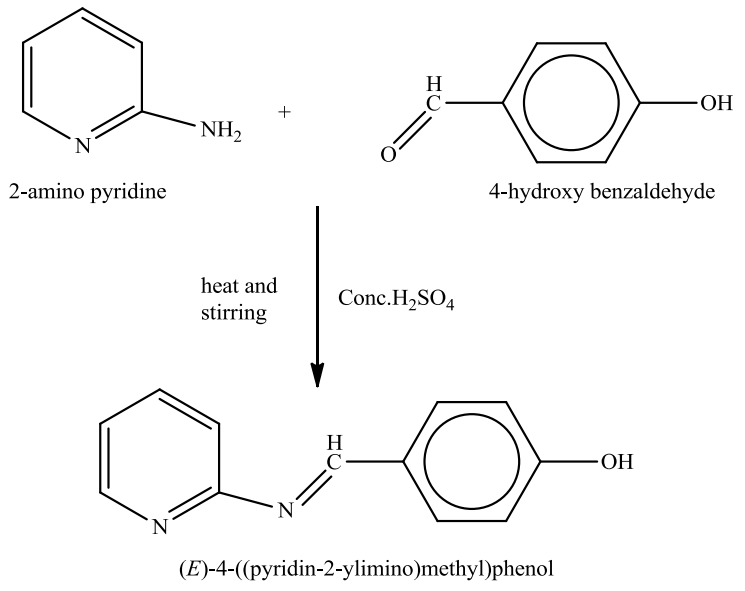

Scheme 1. Structure of Schiff base $\mathrm{L}=\left[\mathrm{C}_{12} \mathrm{H}_{10} \mathrm{~N}_{2} \mathrm{O}\right]$

\subsection{Synthesis of $\mathrm{Mn}(\mathrm{II}), \mathrm{Fe}(\mathrm{II}), \mathrm{Co}(\mathrm{II})$ and $\mathrm{Cd}(\mathrm{II})$ complexes}

All metal complexes were prepared in 1:2 molar ratio (metal : ligand). Methanolic solution $(20 \mathrm{~mL})$ of manganese (II) chloride tetra hydrate $(0.198 \mathrm{~g}, 1 \mathrm{mmol}) / \mathrm{Iron}(\mathrm{II})$ sulphate hexahydrate $(0.278 \mathrm{~g}, 1 \mathrm{mmol}) /$ cobalt(II) chloride hexahydrate $(0.24 \mathrm{~g}, 1 \mathrm{mmol}) /$ cadmimum(II) chloride monohydrate $(0.201 \mathrm{~g}, 1 \mathrm{mmol})$ was taken in a two necked round bottom flask and kept on magnetic stirring. A warm methanolic solution $(20 \mathrm{~mL})$ of prepared Schiff base ligand (0.396 g, 2 mol) was added drop wise and stirred with heating for $4 \mathrm{~h}$. On cooling, precipitates were formed which were filtered, washed with ethanol, acetone, and diethyl ether and dried in vacuum desiccators over anhydrous $\mathrm{CaCl}_{2}$. The purity of each complexe was tested by TLC using different solvents. The complexes were soluble in methanol, DMSO and DMF. The proposed structure of complex was shown in (Scheme 2).

\subsection{Antibacterial studies}

Any chemical or biological agent that either destroys or inhibits the growth of microorganisms is called antimicrobial agent. The synthesized Schiff base ligand and the metal complexes were screened for their antibacterial activity against pathogenic bacterial 


\section{Synthesis and Characterization of Transition Metal Complexes}

strains, Escherichia coli, Pseudomonas aeruginosa and Acetobacer aceti. The disc diffusion method $[25,26]$ was adopted for the determination of antibacterial activity.

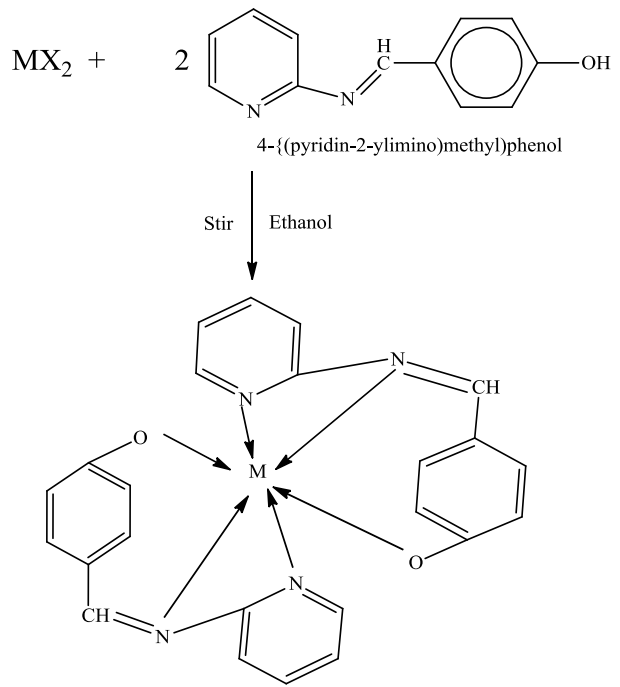

Scheme 2. Structure of metal complexes.

Where $\mathrm{M}=\mathrm{Mn}(\mathrm{II}), \mathrm{Fe}(\mathrm{II}), \mathrm{Co}(\mathrm{II})$ and $\mathrm{Cd}(\mathrm{II})$ and $\mathrm{X}=\mathrm{cl}^{-}, \mathrm{SO}_{4}^{-2}$ ions.

\section{Results and Discussion}

\subsection{Physical properties}

All of the synthesized ligand and metal complexes were air and moisture stable (Table 1). The complexes are intensely colored, amorphous solids, which decomposes above $200^{\circ} \mathrm{C}$. Molar conductance values of the compounds in DMSO $\left(10^{-3} \mathrm{M}\right)$ showed low values (12$45 \mu \mathrm{S} / \mathrm{cm}$ ) indicating [25] them to be non-electrolyte.

Table 1. Physical and analytical data of the Schiff base and metal complexes.

\begin{tabular}{clccc}
\hline Compounds/mol. Formula / Mw. & Color & Yield $(\%)$ & $\begin{array}{c}\text { M.P } \\
\left({ }^{\circ} \mathrm{C}\right) /(\text { decomp })\end{array}$ & $\begin{array}{c}\text { Conductivity } \\
(\mu \mathrm{S} / \mathrm{cm})\end{array}$ \\
\hline $\begin{array}{c}\text { Ligand (L) } \\
\mathrm{C}_{12} \mathrm{H}_{10} \mathrm{~N}_{2} \mathrm{O}[198]\end{array}$ & White & 72 & $180-182$ & 12 \\
\hline $\begin{array}{c}\left.[\mathrm{Mn}(\mathrm{L}))_{2}\right] \\
\mathrm{C}_{24} \mathrm{H}_{18} \mathrm{MnN}_{4} \mathrm{O}_{2}[451]\end{array}$ & White & 62 & $>300$ & 16 \\
\hline $\begin{array}{c}{\left[\mathrm{Fe}(\mathrm{L})_{2}\right] . \mathrm{H}_{2} \mathrm{O}} \\
\mathrm{C}_{24} \mathrm{H}_{20} \mathrm{FeN} \mathrm{O}_{3}[470]\end{array}$ & Yellowish & 58 & $>300$ & 19 \\
\hline$\left[\mathrm{Co}(\mathrm{L})_{2}\right]$ & Pink & 63 & $>300$ & 45 \\
\hline $\mathrm{C}_{24} \mathrm{H}_{18} \mathrm{CoN}_{4} \mathrm{O}_{2}[454]$ & & & \\
\hline
\end{tabular}




\begin{tabular}{ccccc}
\hline Compounds/mol. Formula / Mw. & Color & Yield $(\%)$ & $\begin{array}{c}\text { M.P } \\
\left({ }^{\circ} \mathrm{C}\right) /(\text { decomp })\end{array}$ & $\begin{array}{c}\text { Conductivity } \\
(\mu \mathrm{S} / \mathrm{cm})\end{array}$ \\
\hline $\begin{array}{c}{\left[\mathrm{Cd}(\mathrm{L})_{2}\right] .2 \mathrm{H}_{2} \mathrm{O}} \\
\mathrm{C}_{24} \mathrm{H}_{22} \mathrm{CdN}_{4} \mathrm{O}_{4}[546.41]\end{array}$ & White & 60 & $>300$ & 22 \\
\hline
\end{tabular}

Where, $\mathrm{L}=$ Schiff base ligand $\left[\mathrm{C}_{12} \mathrm{H}_{10} \mathrm{~N}_{2} \mathrm{O}\right]$

\subsection{Infrared spectra}

IR spectra of the Schiff base showed a strong bands at $1662 \mathrm{~cm}^{-1}$ assigned $[25,28]$ to the azomethine, $v(-\mathrm{HC}=\mathrm{N})$ linkage, the bands at 1735 and $3420 \mathrm{~cm}^{-1}$ were absent in Schiff base which are due to carbonyl $v(>\mathrm{C}=\mathrm{O})$ and $v\left(-\mathrm{NH}_{2}\right)$ stretching vibration. It was assumed that amino and aldehyde moieties of the starting reagents were absent and had been converted into the azomethine moiety (Scheme 1). In comparison of the spectra of Schiff base and its metal complexes (Table 2) suggested that each Schiff base coordinated to metal ions using three donors, indicated that the ligand acted as a tridentate ligand. The band appearing at $1666 \mathrm{~cm}^{-1}$ and $1635 \mathrm{~cm}^{-1}$ due to azomethine $(-\mathrm{CH}=\mathrm{N})$ and heterocyclic ring $(>\mathrm{C}=\mathrm{N})$ in a Schiff base was shifted to lower frequency represented [24] the azomethine and heterocyclic ring nitrogen in complexation. Further conclusive evidence of the coordination of Schiff base with metals was shown by appearance of weak low frequency new absorption bands at 509-606 $\mathrm{cm}^{-1}$ and 243-340 $\mathrm{cm}^{-1}$ that assigned [25-27] the metal-oxygen $v(\mathrm{M}-\mathrm{O})$ and metal - nitrogen $v(\mathrm{M}-\mathrm{N})$ frequency respectively.

Table 2. IR spectral data of the schiff base and meta complexes.

\begin{tabular}{llllll}
\hline Ligand/complexes & $v(\mathrm{OH})$ & $v(\mathrm{CH}=\mathrm{N})$ & $v(\mathrm{C}=\mathrm{N})$ & $v(\mathrm{M}-\mathrm{N})$ & $v(\mathrm{M}-\mathrm{O})$ \\
\cline { 2 - 5 } & 3388 & 1662 & 1635 & - & - \\
\hline Ligand $\mathrm{C}_{12} \mathrm{H}_{10} \mathrm{~N}_{2} \mathrm{O}$ & 3369 & 1658 & 1631 & 254 & 519 \\
\hline $\begin{array}{l}\left.[\mathrm{Mn}(\mathrm{L}))_{2}\right] \\
\mathrm{C}_{24} \mathrm{H}_{18} \mathrm{MnN}_{4} \mathrm{O}_{2}\end{array}$ & $3362)$ & 294 & 509 \\
\hline$\left[\mathrm{Fe}(\mathrm{L})_{2}\right] . \mathrm{H}_{2} \mathrm{O}$ & 3332 & 1656 & 1622 & 340 & 606 \\
$\mathrm{C}_{24} \mathrm{H}_{20} \mathrm{FeN}_{4} \mathrm{O}_{3}$ & 3350 & 1645 & 1627 & 243 & 509 \\
\hline$\left[\mathrm{Co}(\mathrm{L})_{2}\right]$ & & 1622 & 243 \\
$\mathrm{C}_{24} \mathrm{H}_{18} \mathrm{CoN}_{4} \mathrm{O}_{2}$ & 3322 & 1654 & 1622 &
\end{tabular}

Where $\mathrm{L}=$ Schiff base ligand $\left[\mathrm{C}_{12} \mathrm{H}_{10} \mathrm{~N}_{2} \mathrm{O}\right]$

\subsection{Magnetic moment and $U V$-Visible spectra}

The magnetic moment and UV-Visible spectral components are recorded in (Table 3). At room temperature magnetic moment values of $\mathrm{Mn}$ (II) complexes was found to $1.93 \mathrm{~B}$. M representing one unpaired electron per $\mathrm{Mn}$ (II) ion. The electronic spectra of $\mathrm{Mn}$ (II) complex showed absorption bands at $26750 \mathrm{~cm}^{-1}$ which may be assigned to $\mathrm{T}_{2 \mathrm{~g}} \longrightarrow \mathrm{Eg}(\mathrm{D})$ similarly, Co(II) complexes was found to 4.3 B. M indicative [29-33] of three unpaired 
electron per $\mathrm{Co}$ (II) ion attaining an octahedral environment. On the other hand, $\mathrm{Fe}$ (II) and Cd(II) complex showed zero magnetic moment that correspond to no unpaired electron per metal ion and suggested low spin octahedral geometry of the complexes. The electronic spectra of the Co(II) complex showed three bands observed at 15391-15473 $\mathrm{cm}^{-1}, \quad 24212-24265 \mathrm{~cm}^{-1}$ and 26720-26803 $\mathrm{cm}^{-1}$ which may be assigned to $4 \mathrm{~A}_{2 \mathrm{~g}} \longrightarrow 4 \mathrm{~T}_{1 \mathrm{~g}}(\mathrm{~F}), 4 \mathrm{~A}_{2 \mathrm{~g}} \longrightarrow 4 \mathrm{~T}_{2 \mathrm{~g}}(\mathrm{~F})$ and $4 \mathrm{~A}_{2 \mathrm{~g}} \longrightarrow 4 \mathrm{~T}_{1 \mathrm{~g}}(\mathrm{P})$ respectively.

Table 3. Magnetic moment and UV-visible spectra of metal complexes.

\begin{tabular}{llll}
\hline Complexes & $\mu_{\text {eff }}($ B.M $)$ & $\lambda_{\text {max }}\left(\mathrm{cm}^{-1}\right)$ & Assignments \\
\hline$\left[\mathrm{Mn}(\mathrm{L})_{2}\right]$ & 1.93 & 26750 & $\mathrm{~T}_{2 \mathrm{~g}} \longrightarrow \mathrm{Eg}(\mathrm{D})$ \\
$\mathrm{C}_{24} \mathrm{H}_{18} \mathrm{MnN}_{4} \mathrm{O}_{2}$ & & & \\
{$\left[\mathrm{Fe}(\mathrm{L})_{2}\right]$} & Diamagnetic & 26315 & $\mathrm{CT}$ \\
$\mathrm{C}_{24} \mathrm{H}_{18} \mathrm{FeN}_{4} \mathrm{O}_{2}$ & & 15380 & $4 \mathrm{~A}_{2} \longrightarrow 4 \mathrm{~T}_{1 \mathrm{~g}}(\mathrm{~F})$ \\
{$\left[\mathrm{Co}(\mathrm{L})_{2}\right]$} & 4.3 & 24275 & $4 \mathrm{~A}_{2 \mathrm{~g}} \longrightarrow 4 \mathrm{~T}_{2 \mathrm{~g}}(\mathrm{~F})$ \\
$\mathrm{C}_{24} \mathrm{H}_{18} \mathrm{CoN}_{4} \mathrm{O}_{2}$ & & 26740 & $4 \mathrm{~A}_{2 \mathrm{~g}}$ \\
{$\left[\mathrm{Cd}(\mathrm{L})_{2}\right]$} & Diamagnetic & 35842 & $\mathrm{CT}$ \\
$\mathrm{C}_{24} \mathrm{H}_{18} \mathrm{CdN}_{4} \mathrm{O}_{2}$ & & & \\
\hline
\end{tabular}

Where, $\mathrm{L}=$ Schiff base ligand $\left[\mathrm{C}_{12} \mathrm{H}_{10} \mathrm{~N}_{2} \mathrm{O}\right]$

\subsection{Thermogravimertic analysis}

TGA was carried out for solid complex $\left[\mathrm{C}_{24} \mathrm{H}_{18} \mathrm{FeN}_{4} \mathrm{O}_{2}\right] \cdot \mathrm{H}_{2} \mathrm{O}$, and $\left[\mathrm{C}_{24} \mathrm{H}_{18} \mathrm{CdN}_{4} \mathrm{O}_{2}\right] \cdot 2 \mathrm{H}_{2} \mathrm{O}$ under $\mathrm{N}_{2}$ flow and heating rate was suitably controlled at $30^{\circ} \mathrm{C} \mathrm{min}^{-1}$ and the weight loss was measured from the ambient temperature up to $800^{\circ} \mathrm{C}$. The TGA and DTG curve of the $\mathrm{Fe}$ (II) complex is shown in (Fig. 1). The maximum temperature values $T \max /{ }^{\circ} \mathrm{C}$, species lost together with the corresponding weight loss for each step of the decomposition reaction was shown in (Table 4). The data obtained strongly supported the proposed formulas of the complex. The data from the TGA, DTA and DTG curve clearly indicated that the decomposition of the $\mathrm{Fe}$ (II) complex proceeds in two steps. In the first step of decomposition, one molecule of hydrated water were lost between $62-360^{\circ} \mathrm{C}$ (calculated $3.83 \%$, experimental $3.75 \%$ of weight) [34]. The Fe(II) complex was completely decomposed between temperature range $450-490^{\circ} \mathrm{C}$ (calculated $84.01 \%$ and experimental $82.03 \%$ ) and above $500^{\circ} \mathrm{C}$ temperature the complex formed as $\mathrm{Fe} / \mathrm{FeO}$. The $\left[\mathrm{C}_{24} \mathrm{H}_{18} \mathrm{CdN}_{4} \mathrm{O}_{2}\right] \cdot 2 \mathrm{H}_{2} \mathrm{O}$ was decomposed into 3 or 4 steps process as shown in (Fig. 2). Two hydrated water molecule were removed between temperature ranges $60-140^{\circ} \mathrm{C}$ (calculated $6.61 \%$ experimental $6.10 \%$ weight loss). The part of $\left(-2 \mathrm{C}_{6} \mathrm{H}_{5} \mathrm{O}^{-}\right)$of the coordinating Schiff base ligand was gradually decomposed between temperatures $160^{\circ} \mathrm{C}$ to $290^{\circ} \mathrm{C}$ (calculated $32.34 \%$, experimental $32.15 \%$ of weight) in second step of decomposition. The other part of the ligand $-2 \mathrm{C}_{5} \mathrm{H}_{4} \mathrm{~N}_{2}$ - was decomposed in third step at $360-430^{\circ} \mathrm{C}$ (calculated $38.60 \%$, experimental $38.12 \%$ of weight). At temperature above $600^{\circ} \mathrm{C}$ the complex formed as $\mathrm{Cd} / \mathrm{CdO}[35,36]$. The proposed degradation pathway [37] 
of the synthesized Cd(II) complex showing order and steps of possible elimination of atoms and groups as shown in (Fig. 3).

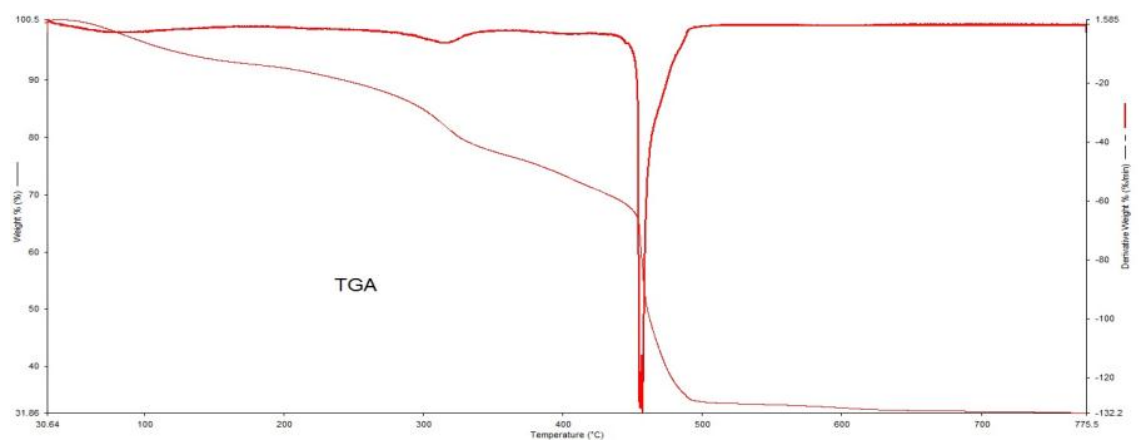

Fig. 1. TGA and DTG curve of $\left[\mathrm{C}_{24} \mathrm{H}_{18} \mathrm{FeN}_{4} \mathrm{O}_{2}\right] \cdot \mathrm{H}_{2} \mathrm{O}$

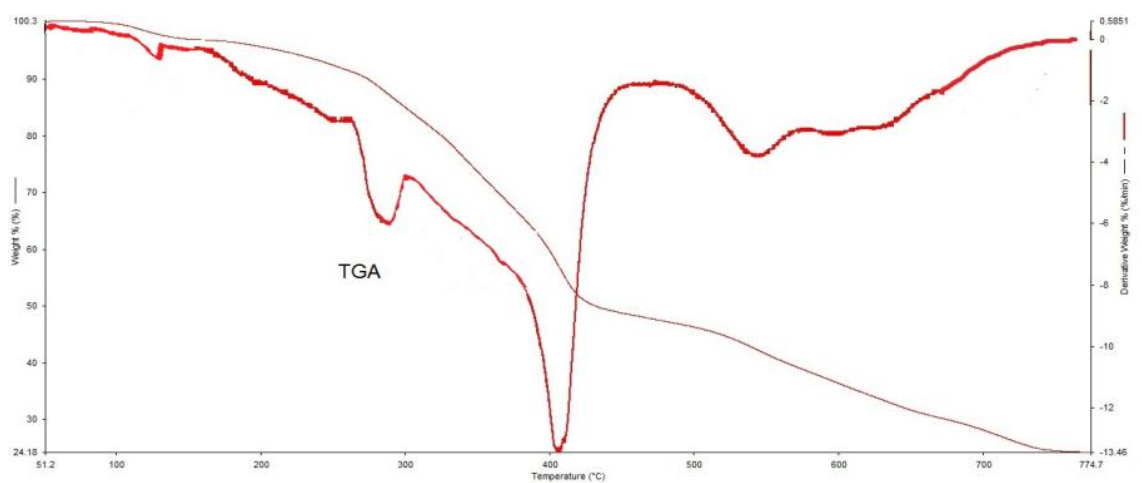

Fig 2. TGA and DTG curve of $\left[\mathrm{C}_{24} \mathrm{H}_{18} \mathrm{CdN}_{4} \mathrm{O}_{2}\right] \cdot 2 \mathrm{H}_{2} \mathrm{O}$

Table 4. Thermal data of Fe(II) and Cd(II) complexes.

\begin{tabular}{llllll}
\hline Complexes & Steps & $\begin{array}{l}\text { Temperature } \\
\text { Range/ }{ }^{\circ} \mathrm{C}\end{array}$ & $\begin{array}{l}\text { DTG } \\
\text { Peak } /{ }^{\circ} \mathrm{C}\end{array}$ & $\begin{array}{l}\text { TG mass loss\% } \\
\text { calc./found }\end{array}$ & Assignments \\
\hline & $1^{\text {st }}$ & $62-360$ & 330 & $3.83 / 3.75$ & $\mathrm{H}_{2} \mathrm{O}$ \\
{$\left[\mathrm{C}_{24} \mathrm{H}_{18} \mathrm{FeN}_{4} \mathrm{O}_{2}\right] \cdot \mathrm{H}_{2} \mathrm{O}$} & $2^{\text {nd }}$ & $450-490$ & 455 & $84.01 / 82.03$ & $2 \mathrm{C}_{12} \mathrm{H}_{9} \mathrm{~N}_{2} \mathrm{O}$ \\
& $3^{\text {rd }}$ & $>500$ & & $11.96 / 11.68$ & $\mathrm{Fe} / \mathrm{FeO}$ \\
\hline & $1^{\text {st }}$ & $60-140$ & 140 & $6.61 / 6.10$ & $2 \mathrm{H}_{2} \mathrm{O}$ \\
& $2^{\text {nd }}$ & $160-290$ & 285 & $32.34 / 32.15$ & $2 \mathrm{C}_{6} \mathrm{H}_{5} \mathrm{O}^{-}$ \\
{$\left[\mathrm{C}_{24} \mathrm{H}_{18} \mathrm{CdN}_{4} \mathrm{O}_{2}\right] \cdot 2 \mathrm{H}_{2} \mathrm{O}$} & $3^{\text {rd }}$ & $360-430$ & 410 & $38.60 / 38.12$ & $2 \mathrm{C}_{5} \mathrm{H}_{4} \mathrm{~N}_{2-}$ \\
& $4^{\text {th }}$ & $>600$ & & $20.58 / 20.10$ & $\mathrm{Cd} / \mathrm{CdO}$ \\
\hline
\end{tabular}




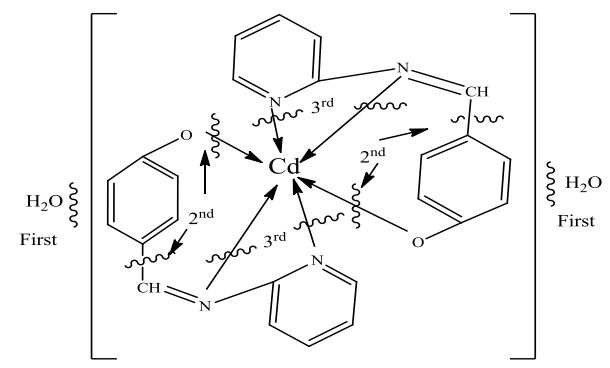

Fig 3. Possible degradation pathway of $\left[\mathrm{C}_{24} \mathrm{H}_{18} \mathrm{CdN}_{4} \mathrm{O}_{2}\right] \cdot 2 \mathrm{H}_{2} \mathrm{O}$

\subsection{Antibacterial properties}

The free Schiff base ligand and their metal complexes were screened for their antibacterial activity against the strains the Escherichia coli, Pseudomonas aeruginosa, Acetobacter aceti. The compounds were tested at a concentration of $40 \mu \mathrm{g} / 0.01 \mathrm{~mL}$ in DMSO solution using the paper disc diffusion method [38,39]. The susceptibility zones were measured in diameter $(\mathrm{mm})$ and the result are listed in (Table 5). The susceptibility zones were the clear zones around the discs killing the bacteria. All the Schiff base and metal complexes individually exhibited varying degrees of inhibitory effects on the growth of tested bacterial species. Most of the metal complexes showed more antibacterial activity than Schiff base ligand.

Table 5. Antibacterial screening activity of Schiff base metal complexes.

\begin{tabular}{|c|c|c|c|c|c|c|}
\hline \multirow{2}{*}{ Tested Bacteria } & \multicolumn{5}{|c|}{ Diameter of zone inhibition(mm) of tested compounds } & \multirow{2}{*}{$\begin{array}{l}\text { Amphicillin } \\
(20 \mu \mathrm{g} / 0.02 \\
\mathrm{mL} / \text { disc })\end{array}$} \\
\hline & Ligand & Mn-complex & Fe-comp & Co-comp & Cd-comp & \\
\hline E.coli & 11 & 12 & 12 & 13 & 07 & 17 \\
\hline Acetobacter aceti & 10 & 10 & 11 & 11 & 12 & 16 \\
\hline $\begin{array}{l}\text { Pseudomonas } \\
\text { Aeruginosa }\end{array}$ & 10 & 09 & 10 & 11 & 11 & 16 \\
\hline
\end{tabular}

\section{Conclusion}

In this paper we have explored the synthesis and coordination chemistry of $\mathrm{Mn}$ (II), $\mathrm{Fe}(\mathrm{II})$, $\mathrm{Co}$ (II) and $\mathrm{Cd}$ (II) complexes with new Schiff base ligand derived from the condensation reaction of 2-amino Pyridine with 4-hydroxy benzaldehyde. The physicochemical analysis indicated the formation of six coordinated metal complexes. IR spectral analysis indicated that $\mathrm{N}$ and $\mathrm{O}$ atoms are coordinated to central metal atom. Magnetic moment, UV-Visible and thermogravimetic analysis confirmed the proposed octahedral structure of metal complexes (Fig. 4). TGA analysis Indicated that Fe(II) complex are more stable than that of $\mathrm{Cd}(\mathrm{II})$ complex. Biological activity revealed that the ligand and its metal complexes have good antibacterial activity as compared to the standard antibiotic (Amphicillin). 


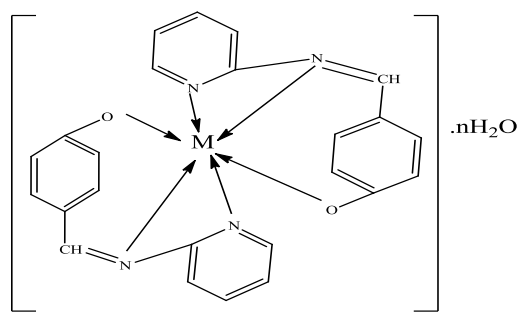

Where, $\mathrm{M}=\mathrm{Mn}(\mathrm{II}), \mathrm{Fe}(\mathrm{II}), \mathrm{Co}(\mathrm{II})$ and $\mathrm{Cd}(\mathrm{II})$

Fig. 4. Proposed structure of M(II) complexes. where, $n=1$ or 2

\section{Acknowledgment}

The authors are thankful to the Science and Technology Ministry of Bangladesh for providing the financial support. We also thank the Chairman, Department of Chemistry, Rajshahi University, Bangladesh for proving the laboratory facilities.

\section{References}

1. H. Schiff, Mittheilungen aus dem Universitatslaboratorium in Pisa; Eine neue reihe organischer basesb. Justus Liebigs Ann Chem, 131(1), 118 (1864).

https://doi.org/10.1002/jlac.18641310113

2. L. A. Banu, M. K. Zahan, M. A. Bashar, M. M. Haque, M. Quamruzzaman, and M. S. Islam, Int. J. Chem. Stud. 2(6), 38 (2015).

3. D. N. Dhar and C. L. Taploo, J. Sci. Ind. Res. 41(8), 501 (1982).

4. M. A. Hossain, M. A. Alam, R. Zahan, C. M. Sheikh, and M. A. A. A. A. Islam, J. Sci. Res. 6(2), 309 (2014). http://dx.doi.org/10.3329/jsr.v6i2.16994

5. Ahmed M. Naglah, Hassan M. Awad, Mashooq A. Bhat, Mohamed A. Al-Omar, and Abd ElGalil E. Amr, J. Chem. 2015, Article ID 364841 (2015). http://dx.doi.org/10.1155/2015/364841

6. N. Raman, S. Sobha, and L. Mitu, Monatsh Chem. 143, 1019 (2012). http://dx.doi.org/10.1007/s00706-011-0699-8

7. A. J. Abdulghani and N. M. Abbas. J. Bioinorganic Chem. Appl. 2011, Article ID 706262 (2011) http://dx.doi.org/10.1155/2011/706262

8. N. Boechat, W.B. Kover, M. M. Bastos, N. C. Romeiro, A. S. C. Silva, F. C. Santos, A. L. Valverde, M. L. G. Azevedo, W. Wollinger, T. M. L. Souza, S. L. O. de Souza, and I. C. P. P. de Frugulhetti., Med. Chem. Res. 15, 492 (2007). http://dx.doi.org/10.1007/s00044$\underline{007-9004-0}$

9. A.O.D. Souza, F. C. S. Galetti, C. L. Silva, B. Bicalho, M. M. Parma, S. F. Fonseca, A. J. M. Angela, C. L. B. Trindade, R. P. F. Gil, F. S. Bezerra, M. Andrade-Neto, and M. C. F. de Oliveira, Quim Nova. 30(7), 1563 (2007). https://doi.org/10.1590/S0100-40422007000700012

10. S. Jain, A. Sharma, M. Agrawal, S. Sharma, J. Dwivedi, and D. Kishore, J. Chem. 2013, Article ID 925439 (2013) http://dx.doi.org/10.1155/2013/925439

11. G. S. Kurdekar, M. P. Sathisha, S. Budagumpi, N. V. Kulkarni, and D. K. Suresh, Med. Chem. Res. 21, 2273 (2012). http://dx.doi.org/10.1007/s00044-011-9749-3

12. M. N. Patel, C. R. Patel, and H. N. Joshi, Appl. Biochem. Biotechnol. 169, 1329 (2013). http://dx.doi.org/10.1007/s12010-012-0086-x

13. J. M. Pratt, Inorganic Chemistry of Vitamin B (Academic press, London, 1970). 
14. S. K. Shapiro and F. Schlenk, Transmethylation and Methionine Biosynthesis (University of Chicago Press, Chicago, 1965)

15. J. M. Walshe, Brit. J. Hospit. Med. 6, 45 (1970).

16. M. J. Clare and J. D. Heeschele, Bioinorg. Chem. 2, 187 (1973).

17. M. Barboiu, C. T. Supuran, A. Scozzafava, C. Guran, P. Diaconescu, M .Bojin, V. lluc, L. Cot, and L. Cot, Metal-Based Drugs 6, 101 (1999).

18. D. de Vos, P. Clements, S. M. Pyke, D. R. Smyth, and E. R. T. Tiekink, Metal-Based Drugs 6, 31 (1999). https://doi.org/10.1155/MBD.1999.31

19. M. Geraghly, M. Devereux, F. C. Curran and V. Mckee, Metal Based Drugs 6, 41 (1999).

20. A. Mastrolorenezo and C. T. Supuran, Metal-Based Drugs 7, 49 (2000). https://doi.org/10.1155/MBD.2000.49

21. A. Scozzavafa, L. Menabuoni, F. Minncone, and C. T. Supuran, Bioorg. Med. Chem. Lett. 11, 575 (2001). https://doi.org/10.1016/S0960-894X(01)00266-9

22. E. H. Ismail, D. Y. Sabry, H. Mahdy, and M. M. H. Khalil, J. Sci. Res. 6(3), 509 (2014). http://dx.doi.org/10.3329/jsr.v6i3.18750

23. M. Al-Amin-Al-Azadul Islam, M. A. Mumit, T. K. Pal, and M. A. Alam. J. Sci. Res. 4(3), 635 (2012). http://dx.doi.org/10.3329/jsr.v4i3.9807

24. Z. H. Chohan, A. Munawar, and C. T. Supuran, Transition Metal Complexes of Some Schiff Bases Synthesis Characterization and Antibacterial Studies. Metal based drugs. 8(3), 137 (2001). http://dx.doi.org/10.1155/MBD.2001.137,

25. M. S. Hossain, M. A. Islam, C. M. Zakaria, M. M. Haque, M. A. Mannan, and M. K. Zahan, J. Chem. Bio. Phy. Sci. 6(1), 041 (2016). https://www.researchgate.net/publication/309512258

26. M. Shiraj-U-Ddaula1, M. A. Islam, S. Aktar, M. K. Islam, and M. K. Zahan, Asian J. Res. Chem. 7(7), (2014). https://www.researchgate.net/publication/277137032

27. M. A. Subhan, K. Alam, M. S. Rahaman, M. A. Rahman, and M. R. Awal. J. Sci. Res. 6(1), 97 (2014). http://dx.doi.org/10.3329/jsr.v6i1.15381

28. K. Nakamoto, Infrared Spectra of Inorganic and Coordination compounds, $2^{\text {nd }}$ edition (Wiley Inter-science, New York, 1970).

29. B. N. Fiqqis, Introduction to Ligand Field (John Wiley, New York, 1976)

30. B. P. Lever, Inorganic Electronic Spectroscopy (Elsevier, Amsterdam, 1984).

31. D. Liethr J. Phys. Chem. 67, 1314 (1967);

32. T. M. Duun, J. Lews, and R. C. Wlkms, The Visible and Ultraviolet Spectra of Complex Compounds in Modern Coordination Chemistry (Interscience, New York, 1960).

33. Z. H. Chohan and S. K. A. Sherrazi, Synth. React. Inorg. Met-Org. Chem. 29, 106 (1999). https://doi.org/10.1080/00945719909349437

34. M. T. S. Ristovic, D. M. Minic, D. Poleti, Z. Miodragovic, Đ. Miodragovic, and K. K. Andelkovic, J. Therm. Anal. Calorim., 102, 83 (2010). http://dx.doi.org/10.1007/s10973-010-0748-2

35. S. Alghool, H. F. A. El-Halim, M. A. El-sadek, I. Yahia, and L. Wahab, J. Therm. Anal. Calorim. 112, 671 (2013). http://dx.doi.org/10.1007/s10973-013-3477-5

36. S. Alghool, H, F, A, El-Halim, M. A. El-sadek, I. Yahia, and L. Wahab, J. Therm. Anal. Calorim. 121, 1309 (2015). http://dx.doi.org/10.1007/s10973-015-4610-4

37. M. R. Islam, J. A. Shampa, M. K. Zahan, M. M. Haque, and Y. Reza. J. Sci. Res. 8(2), 181 (2016). http://dx.doi.org/10.3329/jsr.v8i2.26332

38. B. Anupam and C. G. Kumari, J. Sci. Res. 6(3), 487 (2014). http://dx.doi.org/10.3329/jsr.v6i3.16993

39. T. K. Pal, M. A. Alam, M. A. A. A. A. Islam, and S. R. Paul, J. Sci. Res. 4(2), 427 (2012). http://dx.doi.org/10.3329/jsr.v6i3.16993 